DOI https://doi.org/10.30525/978-9934-588-80-8-1.64

\title{
ОРГАНІЗАЦІЯ НЕДІЛЬНИХ ШКІЛ В ВСО ЄХБ. ТЕНДЕНЦІї. ПЕРСПЕКТИВИ
}

\author{
Чаплинський В. Г. \\ аспірант кафедри релігієзнавства \\ Начіональний університет "Острозька академія» \\ м. Острог, Рівненська область, Україна
}

Актуальність: в церквах ВСО СХБ потрібно приділяти більше уваги освіті в недільних школах, тому що це визначає життя наступного покоління. Громади ВСО СХБ не мали до дев'яностих років 20 століття систематичної освіти в недільних школах і стали перед проблемою його організації. Але для цього необхідно вдосконалити форми i методи освіти, виробити нові прийоми освіти, адаптувати закордонні методи навчання дітей до місцевих умов. Дані процеси отримали розвиток в зв'язку з трансформацією українського суспільства.

Мета: описати форми і методи освіти в недільних школах ВСО ЄХБ. Об'єкт: освіта в церквах в ВСО СХБ.

Предмет: освіта в недільних школах ВСО СХБ.

У новій обстановці відкритого суспільства з'явилися проблеми 3 проектуванням і реалізацією систем християнської освіти. Свангельські християни-баптисти десятиліттями відірвані від систематичноі богословської освіти стали перед проблемою організації християнської освіти на новій основі. У зв'язку з цим українські баптисти змушені були звернутися до зарубіжних програм навчання дітей [3].

Збільшення кількості церков з початку дев'яностих років послужило подальшому зростанню недільних шкіл. Це сприяло адаптації молоді в церквах і омолодженню лідерського складу об'єднання ВСО ЄХБ.

Хоча адаптація до сучасних умов відбувалася в недостатній мірі через недосконалість форм i методів виховання i секуляризації середовища, в якій опинилися діти. Це вплив вулиці, зміст масової інформації, комп'ютерні ігри, Інтернет і інше, що негативно впливає на зростання кількості дітей в недільній школі. 3'явилася тенденція організації приватних християнських шкіл. У цих школах поряд зі світською освітою додатково викладаються предмети релігійного змісту. Нові прийоми дитячого освіти запропонували зарубіжні місії. Однак виникла критика цих програм у зв'язку з невідповідністю традиції східних і західних церков [5].

Розвиток богословсько-освітньої середовища в 1990-2004 р є одним 3 напрямків інституалізації ВСО СХБ. Дана трансформація стало відображенням змін, які відбулися в українському суспільстві. 
Необхідність вивчення освітнього середовища $є$ актуальним в даний час. Починається вивчення освітнього середовища 3 дитячої недільної школи, для функціонування якої розроблені необхідні програми для кожної вікової категорії.

Перша програма з'явилася в Одеській семінарії під назвою «Ключ». Дана програма створена таким чином, щоб виявити індивідуальні схильності кожної дитини, щоб потім використовувати їх в церковнім мікросередовищі. Важливо в християнському вихованні дітей організація вільного часу в літній час, в канікулярні дні і під час богослужінь. Відмінною особливістю методик з проведення уроків у недільній школі для дітей - це використовувати всі можливі методи зосередження уваги на вивченні Святого Письма.

Християнська освіта в дев'яностих роках XX ст. на Україні почалася з недільної школи. Перша програма для недільної школи була запозичена у Південній Баптистської конвенції США, інші програми також мали закордонний вплив. Але, щоб організувати християнську освіту, необхідно мати адаптовані навчальні та методичні матеріали для українських церков і підготовлених на цих матеріалах педагогів [4].

Всі уроки в недільній школі носять євангелізаційний характер. Вони викладають біблійні доктрини. Ці уроки були ретельно відредаговані і можуть застосуватися для читання в родинному колі. Необхідність недільної школи в церкві сьогодні актуальна. Свангельські церкви розширюють роботу в недільній школі не тільки для відвідувачів церкви, а й для тих що проживає поряд .

Уроки в недільній школі подають конспекти занять. Ці уроки включають головні теми Старого Нового заповітів в систематичному викладі. На базі організованої недільної школи може вирости церква[2].

На уроках недільної школи використовують Біблійні розповіді. Кожен урок розрахований на те, щоб дати правильне розуміння $\mathrm{i}$ привести до прийняття християнського світогляду. Програма недільної школи розрахована на знайомство з біблійними подіями у відповідному порядку: Старий Заповіт розглядається хронологічно, але уроки по Старого завіту можуть чергуватися і з уроками з Нового Завіту. Тут враховується потреба дітей в пастирському служінні. Уроки можуть публікуватися в християнських журналах у відповідних рубриках. Вони можуть вживатися для дитячих зборів, такі як дитячі вечора.

Існує багато методик для недільних шкіл, які припускають конспекти для різних вікових груп. Недільні школи відрізняються один від одного за своїм характером і змістом, що відповідає даному мікро середовищу.

Біблійні уроки необхідно приготувати так, щоб вони могли стати в нагоді віковим групам, починаючи 3 дошкільних вікових категорій i закінчуватися підлітками. Якщо старші класи зазвичай використовують цілком тематику уроків, то молодші менше кількості матеріалу. 
Програма уроків може розроблятися приблизно на один навчальний рік. Крім того можна ділити програму на таку ж кількість чвертей в році, що і звичайних денних школах. Навчання переривається на свята: Різдво, Новий рік, Великдень, в канікулярний час. Під час канікул для дітей готують теми відмінні від програми в школі.

Проводяться також християнські фестивалі та фестивалі недільної школи. Тут проводиться робота 3 метою зробити навчання більш ефективним. Проводяться спеціалізовані виставки для оснащення вчителів недільної школи. На них презентуються нові розробки уроків та методичні матеріали [4].

Існує дитяче служіння за межами церкви. Міжнародні християнські організації несуть служіння в сфері дитячого служіння. Служіння також проходить за наступними напрямками: викладання християнської етики в загальноосвітніх школах, служіння дітям-сиротам, гуманітарна допомога.

Місія «Живе слово» (Рівно) проводить культурно-просвітницьку діяльність, розвиває духовні здібності у дітей, звертаючи їхню увагу на моральні і етичні питання. Завдяки цьому діти відвідують недільні школи в церквах, приводять на служіння інших дітей, діляться матеріалами 3 журналу «Ноїв Ковчег». Існує листування 3 читачами цього журналу.

Служіння орієнтоване на роботу дітьми. Створена дитяча редколегія, де програми і заходи розробляються 3 дітьми. У 2003 році завдяки фінансовій підтримці «Надія України» почав свою діяльність клуб «Майбутнє України». Це клуби для дітей віком від 7 до 15 років, в яких діти активно розвивають свої інтелектуальні, фізичні та творчі здібності.

Дана робота потребує грамотних викладачів, так як церкви не приділяють питанню дитячого служіння належної уваги. У роботі 3 дітьми протягом декількох років не змінюються форми і методи. Винятками є «Школа без стін», яка має високі показники в роботі 3 дітьми [6]. Баптистським церквам потрібно приділяти більше уваги, часу служінню дітям, тому що в подальшому вони будуть визначати життя наступного покоління.

Робота центру «Нарнія» укладена в виданні християнської літератури для дітей, а також методичної літератури для батьків i вчителів. Проводяться семінари для тих, хто працює 3 дітьми та дитячих письменників. Через журнал «Нарнія» проводиться також просвітницька діяльність.

Висновок. Збільшення кількості церков ВСО ЄХБ 3 початку дев'яностих років послужило організації християнської освіти в недільних школах. Робота $з$ дітьми налагоджена через різні програми i взасмодії з церквами. Завдяки підтримці міжнародних місій можна побачити нові можливості в дитячому служінні. Видається 
християнська література для дітей та методична література для батьків і вчителів. Здійснюється заняття по листуванню з вихованцями дитячих будинків та інтернатів. За допомогою спортивних ігор дітям пояснюють християнські цінності. Проводяться дитячі денні табори 3 вивченням англійської мови. Створено кореспондентські курси і он лайн навчання. Налагоджена культурно-просвітницька діяльність, розвиваються духовні здібності у дітей. Викладається християнська етика в загальноосвітніх школах. Сиротам і дітям із бідних сімей, інвалідів надається гуманітарна допомога.

\title{
Література:
}

1. Гебелайн Ф. Образ истины Божией. Международная ассоциация христианских школ. - 1995. - С. 25.

2. Дениел Э., Уэйд Д. Основы христианского образования. Симферополь - 2005. - С. 140.

3. Мокієнко М.М. «Пізній протестантизм в Україні: інституційний та суспільно-політичний аспекти (1991-2004 р.p.). Дис. На здобуття наукового ступеня канд. істор. наук.- Запоріжжя.-2007 - с.73

4. Моррис Г. Христиаское образование для реального мира. - М., «Пртестант», - 1993. - С. 127.

5. Уилхойт Д., Райкен Л. Эффективное преподавание Библии. C. 73 .

6. Школа без стен - Коростень: МЧП «Триада С»-2016 - 123 с.

DOI https://doi.org/10.30525/978-9934-588-80-8-1.65

\section{ІСТОРІОГРАФІЯ ОСВІТИ УЧНІВ ПОЧАТКОВОЇ ШКОЛИ У ВЕЛИКІЙ БРИТАНІї В 50-ТІ РОКИ ХХ СТОЛІТТЯ}

\author{
Чевелюк М. В. \\ аспірант кафедри іноземної філологї̈ та перекладу \\ Відкритий міжнародний університет розвитку людини «Украӥна» \\ м. Київ, Україна
}

Освіта у Великій Британії зазнала величезних змін у післявоєнні часи. Усі три рівні освіти - початкова, середня та вища, зазнавали занепокоєння 3 приводу неадекватності та нерівності на кожному 3 трьох етапах навчання. Обурення набуло поширення серед батьків, вчителів та адміністраторів. Наприкінці одинадцяти років правління торі заклики до змін досягали апогею. 